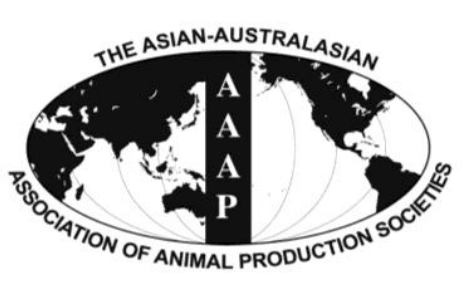

Open Access

Asian Australas. J. Anim. Sci.

Vol. 27 , No. 7 : $937-945$ July 2014

http://dx.doi.org/10.5713/ajas.2013.13387

www.ajas.info

pISSN 1011-2367 elSSN 1976-5517

\title{
Fermentation Characteristics, Tannin Contents and In vitro Ruminal Degradation of Green Tea and Black Tea By-products Ensiled at Different Temperatures
}

\author{
Makoto Kondo $^{1,2, *}$, Yoshiaki Hirano ${ }^{2,3}$, Kazumi Kita ${ }^{2,4}$, Anuraga Jayanegara ${ }^{5}$, and Hiro-omi Yokota ${ }^{2}$ \\ ${ }^{1}$ Department of Bioresources, Mie University, Tsu, Mie 514-8507, Japan
}

\begin{abstract}
Green and black tea by-products, obtained from ready-made tea industry, were ensiled at $10^{\circ} \mathrm{C}, 20^{\circ} \mathrm{C}$, and $30^{\circ} \mathrm{C}$. Green tea by-product silage (GTS) and black tea by-product silage (BTS) were opened at 5, 10, 45 days after ensiling. Fermentation characteristics and nutrient composition, including tannins, were monitored and the silages on day 45 were subjected to in vitro ruminal fermentation to assess anti-nutritive effects of tannins using polyethylene glycol (PEG) as a tannin-binding agent. Results showed that the GTS and BTS silages were stable and fermented slightly when ensiled at $10^{\circ} \mathrm{C}$. The GTS stored at $20^{\circ} \mathrm{C}$ and $30^{\circ} \mathrm{C}$ showed rapid $\mathrm{pH}$ decline and high acetic acid concentration. The BTS was fermented gradually with moderate change of $\mathrm{pH}$ and acid concentration. Acetic acid was the main acid product of fermentation in both GTS and BTS. The contents of total extractable phenolics and total extractable tannins in both silages were unaffected by storage temperatures, but condensed tannins in GTS were less when stored at high temperature. The GTS showed no PEG response on in vitro gas production, and revealed only a small increase by $\mathrm{PEG}$ on $\mathrm{NH}_{3}-\mathrm{N}$ concentration. Storage temperature of GTS did not affect the extent of PEG response to both gas production and $\mathrm{NH}_{3}-\mathrm{N}_{\text {concentration} \text {. }}$ On the other hand, addition of PEG on BTS markedly increased both the gas production and $\mathrm{NH}_{3}-\mathrm{N}$ concentration at any ensiled temperature. It can be concluded that tannins in both GTS and BTS suppressed rumen fermentation, and tannins in GTS did more weakly than that in BTS. Ensiling temperature for both tea by-products did not affect the tannin's activity in the rumen. (Key Words: Tea By-product, Silage Fermentation, Tannin, In vitro Ruminal Degradation)
\end{abstract}

\section{INTRODUCTION}

Consumption of ready-made green and black tea in cans, packs or bottles has increased remarkably in recent years in Japan, and East Asian and Southeast Asian countries. Beverage companies that manufacture various tea drinks

\footnotetext{
* Corresponding Author: Makoto Kondo. Tel: +81-59-231-9625, Fax: +81-59-231-9684, E-mail: makok@ bio.mie-u.ac.jp

${ }^{2}$ Nagoya University Farm, Nagoya University, Togo, Aichi 4700151, Japan.

${ }^{3}$ Department of Health and Nutrition, Tokai Gakuen University, Nagoya, Aichi 468-8514, Japan.

${ }^{4}$ Department of Agriculture, Iwate University, Morioka, Iwate 020-8550, Japan.

${ }^{5}$ Department of Nutrition and Feed Technology, Bogor Agricultural University, Bogor 16680, West Java, Indonesia.

Submitted Jul. 4, 2013; Revised Aug. 26, 2013; Accepted Mar. 26, 2014
}

produce numerous tons of used tea leaves annually as byproducts. Previous reports have shown that these kinds of tea by-products generally contained high crude protein $(\mathrm{CP})$ fiber and tannins (e.g., Kondo et al., 2004a; Wang et al., 2011; Ramdani et al., 2013). Tea by-products also contain high moisture (about $800 \mathrm{~g} / \mathrm{kg}$ ); consequently, they deteriorate easily after their release as a by-product. It is therefore necessary to develop the preservation means of tea by-product as a feed resource. Accordingly, ensiling apparently is a suitable means to preserve agricultural or food industrial by-products (Nishino et al., 2003; Wang et al., 2011; Mokhtarpour et al., 2012). In the case of tea byproducts, they are produced throughout the year from beverage companies, therefore, the ensiling temperature might affect the fermentation pattern and end products of tea by-product silage.

Due to high content of tannin in tea by-products, 
attention must be given to tannin's activity when they are used instead of commercial feed in livestock production. Many investigations into beneficial and problematic effects of tannin on ruminant nutrition have been reported (Waghorn, 2008). Ingestion of moderate level of tannin increase the absorption of amino acids from small intestine, improve animal performance and so on (Waghorn, 2008; Pathak et al., 2013; Hymes-Fecht et al., 2013). On the other hand, animals fed tannin-rich diets showed decreased feed intake, increased fecal $\mathrm{N}$ excretion, reduced digestibility, and less ruminal degradability (Waghorn, 2008; Tan et al., 2011; Kozloski et al., 2012). Effects of tannin on feed degradability have been studied in several ways, e.g., in sacco and in vitro. For these methods, polyethylene glycol (PEG) has been used as a tannin binding agent in a bioassay system that shows the effects of tannin on nutrient degradability in the digestive tract, especially in the rumen (Rubanza et al., 2003; Bhatta et al., 2012).

This study examines the fermentation characteristics and changes in phenolics and tannin contents of green tea and black tea by-products ensiled at different temperatures. PEG is also used in this study to bind tannins in order to examine the effects of ensiling on in vitro ruminal fermentation responses to tannins.

\section{MATERIALS AND METHODS}

\section{Silage preparation}

Green and black tea by-products were acquired from a local ready-made tea drink factory, and moved to Nagoya University Farm in a few hours. Approximately $700 \mathrm{~g}$ of tea by-products were packed into polyethylene bags (255 $\mathrm{mm} \times 350 \mathrm{~mm} \times 0.08 \mathrm{~mm}$ ) and tying with string after removing air to close the upside of each bag. Bags were stored at three different temperatures, $10^{\circ} \mathrm{C}, 20^{\circ} \mathrm{C}$, and $30^{\circ} \mathrm{C}$ in climate chambers, and opened 5, 10 and 45 days after ensiling. Silages were made in triplicates for each temperature and ensiling period.

\section{In vitro ruminal gas production and ammonia production}

The samples of tea by-products before ensiling and their silages on day 45 were incubated in vitro with rumen fluid in calibrated glass syringes (Menke and Steingass, 1988). Each sample was freeze-dried and ground to pass through $1 \mathrm{~mm}$ screen. Rumen fluid was obtained before morning feeding from three castrated Japanese Shiba goats fed on $720 \mathrm{~g}$ hay and $180 \mathrm{~g}$ commercial concentrates that were offered in equal proportions twice a day. Prepared buffer solution and ruminal fluid were mixed at a ratio of 2:1. The $100 \mathrm{~mL}$ calibrated glass syringes containing $500 \mathrm{mg}$ of samples with or without 1,000 mg of PEG (MW:6,000) and $40 \mathrm{~mL}$ of buffered rumen fluid were incubated in a water bath at $39^{\circ} \mathrm{C}$ in triplicates (Getachew et al., 2000). Gas production was measured at 3, 6, 9, 12 and 24 hours, and at the end of the incubation, the fermentation fluid was collected from the syringes. After centrifugation $(1,090 \times g)$, the supernatant was collected and frozen at $-30^{\circ} \mathrm{C}$ until ammonia nitrogen $\left(\mathrm{NH}_{3}-\mathrm{N}\right)$ analysis.

\section{Chemical and microbial analyses}

Dry matter (DM) was determined by oven drying at $60^{\circ} \mathrm{C}$ for $48 \mathrm{~h}$. Twenty g of tea by-products and their silages were macerated with $100 \mathrm{~mL}$ of distilled water. The macerate was filtered, and the filtrate was subjected to determination of $\mathrm{pH}$, lactic acid, acetic acid, propionic acid, butyric acid, and $\mathrm{NH}_{3}-\mathrm{N}$. The $\mathrm{pH}$ values and lactic acid concentrations were measured potentiometrically and colorimetrically, respectively (Barnett, 1951). Concentrations of acetic acid, propionic acid, and butyric acid were detected with a gas chromatograph using a FALM column (Shimadzu Co., Kyoto, Japan). $\mathrm{NH}_{3}-\mathrm{N}$ of silage was determined by steam distillation. Silages were weighed before and after ensiling, and the DM loss was calculated. Viable counts of lactic acid bacteria (LAB) associated with original tea by-products and the silages were measured using de Man, Rogosa, Sharpe (MRS) agar plate. The counts were expressed as colony forming unit (cfu) on a fresh matter (FM) base. Samples were freeze-dried and ground to pass through $1 \mathrm{~mm}$ screen for the following analysis. Buffering capacity of materials was measured by titration using the dried sample (Playne and McDonald, 1966). Total nitrogen (N) content was determined by the Kjeldahl method and $\mathrm{CP}$ content was calculated as $6.25 \times \mathrm{N}$. Neutral detergent fiber (NDF), acid detergent fiber (ADF) and acid detergent lignin (ADL) were analyzed as outlined by Van Soest et al. (1991). Cellulose and hemicellulose were calculated by subtracting ADL from ADF and ADF from NDF, respectively. Neutral detergent insoluble CP (NDICP) and acid detergent insoluble CP (ADICP) were determined by the method of Licitra et al. (1996). Watersoluble carbohydrate (WSC) concentrations were determined using the anthrone reaction rate assay (Koehler, 1952). Total extractable phenols (TEPH), total extractable tannins (TET), and condensed tannins (CT) of freeze-dried samples were analyzed by the methods of Makkar and Goodchild (1996). For in vitro gas production test, $\mathrm{NH}_{3}-\mathrm{N}$ in the culture was determined using the indophenol reaction (Weatherburn, 1967).

\section{Statistical analyses}

Fermentation characteristics and chemical composition of silages on day 45 were analyzed by a one-way analysis of variance (ANOVA) and further tested using tukey's test to compare among various treatment means. Data of in vitro ruminal gas production and $\mathrm{NH}_{3}-\mathrm{N}$ concentration from 
materials and silages on day 45 were analyzed by ANOVA, taking into account different batch of rumen fluid for each incubation run, and tested using tukey's test as above. Effect of PEG on gas production and $\mathrm{NH}_{3}-\mathrm{N}$ concentration of incubated medium was analyzed by Student's t-test. All analyses were performed by SAS software version 9.3. (SAS Institute Inc., Cary, NC, USA).

\section{RESULTS AND DISCUSSION}

\section{Chemical composition of tea by-products}

Both tea by-products contained low DM, WSC, and buffering capacity (Table 1). The numbers of LABassociated with both kinds of tea by-products were high (about $10^{6} \mathrm{cfu} / \mathrm{g} \mathrm{FM}$ ) as compared with forage (McDonald et al., 1991). CP contents in both tea by-products were close to $300 \mathrm{~g} / \mathrm{kg}$ DM that were in consistent with Wang et al. (2011). As CP fractions, slowly- and less-degradable protein in black tea by-product was assumed to be higher than in green tea by-product according to NDICP and ADICP contents, respectively (Licitra et al., 1996). Black tea byproduct had higher NDF content, which may be affected by the high NDICP content. The ADF and ADL were similar between two kinds of tea by-products. Phenolic compounds were comparable in both tea by-products and these levels were moderate as compared with some tropical browse

Table 1. Chemical characteristics and lactic acid bacteria of green and black tea by-product before ensiling

\begin{tabular}{lcc}
\hline Attributes & $\begin{array}{c}\text { Green tea } \\
\text { by-product }\end{array}$ & $\begin{array}{c}\text { Black tea } \\
\text { by-product }\end{array}$ \\
\hline Dry matter (DM, g/kg) & $196 \pm 0.9$ & $183 \pm 1.1$ \\
Water soluble carbohydrate & $10 \pm 0.2$ & $11 \pm 0.4$ \\
$\quad$ (g/kg DM) & & \\
Buffering capacity & $206 \pm 2.3$ & $186 \pm 2.2$ \\
$\quad$ (meq/kg DM) & & \\
Lactic acid bacteria & $6.28 \pm 0.08$ & $6.28 \pm 0.12$ \\
$\quad(\log 10$ cfu/g FM) & & \\
CP (g/kg DM) & $292 \pm 1.9$ & $290 \pm 1.3$ \\
NDICP (g/kg CP) & $165 \pm 6.4$ & $519 \pm 6.0$ \\
ADICP (g/kg CP) & $70 \pm 2.1$ & $99 \pm 2.0$ \\
NDF (g/kg DM) & $386 \pm 6.0$ & $466 \pm 9.0$ \\
ADF (g/kg DM) & $289 \pm 4.2$ & $277 \pm 5.1$ \\
ADL (g/kg DM) & $96 \pm 0.9$ & $93 \pm 1.3$ \\
Hemicellulose (g/kg DM) & $97 \pm 3.4$ & $189 \pm 7.3$ \\
Cellulose (g/kg DM) & $193 \pm 4.9$ & $184 \pm 3.5$ \\
TEPH (g/kg DM) & $81 \pm 2.1$ & $94 \pm 0.9$ \\
TET (g/kg DM) & $74 \pm 2.5$ & $70 \pm 1.2$ \\
CT (g/kg DM) & $21 \pm 0.4$ & $11 \pm 0.4$ \\
\hline
\end{tabular}

cfu, colony forming unit; FM, fresh matter; $\mathrm{CP}$, crude protein; NDICP, neutral detergent insoluble $\mathrm{CP}$; ADICP, acid detergent insoluble CP; NDF, neutral detergent fiber; ADF, acid detergent fiber; ADL, acid detergent lignin; TEPH, total extractable phenolics; TET, total extractable tannins; $\mathrm{CT}$, condensed tannins. species (Osuga et al., 2005).

\section{Fermentation characteristics of tea by-products ensiled at different temperatures}

The GTS and BTS stored at $10^{\circ} \mathrm{C}$ showed small changes in $\mathrm{pH}, \mathrm{NH}_{3}-\mathrm{N}$ and acid production for ensiling periods (Figures 1 and 2). At low temperatures, such as those of winter season, tea by-product silage produced only a small amount of acid with high $\mathrm{pH}$, but the condition could be stabilized if the by-products were packed without air. The GTS stored at $20^{\circ} \mathrm{C}$ and $30^{\circ} \mathrm{C}$ showed a rapid decrease of $\mathrm{pH}$ around 5 days after ensiling. Subsequently, the $\mathrm{pH}$ was maintained below 4.2 during ensiling. On the other hand, the BTS stored at $30^{\circ} \mathrm{C}$ exhibited the lowest $\mathrm{pH}$ (4.28), followed by $20^{\circ} \mathrm{C}(4.48)$ and $10^{\circ} \mathrm{C}(5.26)(\mathrm{p}<0.05)$. A rapid $\mathrm{pH}$ decrease was apparent in the silage stored at $30^{\circ} \mathrm{C}$ until day 5 and gradual decrease at $20^{\circ} \mathrm{C}$ through ensiling period. Specific characteristics of tea by-product silages were the organic acid contents. Both GTS and BTS stored at $20^{\circ} \mathrm{C}$ and $30^{\circ} \mathrm{C}$ contained acetic acid mainly, resulting in a pH decrease. Acetic and propionic acid in GTS were produced mainly at early stages of ensiling, but they increased gradually in BTS stored at $20^{\circ} \mathrm{C}$ and $30^{\circ} \mathrm{C}$ through ensiling periods. In contrast to acetic acid, lactic acid was low in GTS and negligible in BTS. On day 45 , the lactic acid content of GTS was the highest in stored at $20^{\circ} \mathrm{C}(9.3 \mathrm{~g} / \mathrm{kg}$ $\mathrm{DM})$, followed by at $30^{\circ} \mathrm{C}$ and $10^{\circ} \mathrm{C}(<3.8 \mathrm{~g} / \mathrm{kg} \mathrm{DM})$. Lactic acid in BTS was not detected during 10 days at any temperature; it was present in small quantities on day 45 $(0.2 \mathrm{~g} / \mathrm{kg} \mathrm{DM})$. Counts of LAB in both silages increased during 5 days of ensiling and they maintained above $10^{6}$ cfu/g FM at all temperatures. However, these high LAB counts did not effect on lactic acid concentration in GTS and BTS. The $\mathrm{pH}$ decrease was almost parallel with the increase of acetic acid. Although acidification by acetic acid is less prevalent than that by lactic acid, GTS and BTS showed low $\mathrm{pH}$, which could be due to the low buffering capacity of the materials compared with forage (200 to 600 $\mathrm{meq} / \mathrm{kg} \mathrm{DM}$ ) (McDonald et al., 1991). Butyric acid was not detected in either GTS or BTS at $10^{\circ} \mathrm{C}$ and was low at $20^{\circ} \mathrm{C}$ and $30^{\circ} \mathrm{C}(<5 \mathrm{~g} / \mathrm{kg} \mathrm{DM})$. The sum of lactic acid, acetic acid, propionic acid and butyric acid was high in GTS stored at both $20^{\circ} \mathrm{C}$ and $30^{\circ} \mathrm{C}$ (approximately $50 \mathrm{~g} / \mathrm{kg} \mathrm{DM}$ ), but it was high only at $30^{\circ} \mathrm{C}$ in BTS. According to the rate of $\mathrm{pH}$ decrease and acid accumulation, green tea by-product can be more fermentable than black tea by-product by ensiling. GTS was preserved well with low $\mathrm{pH}$, but effluent was also found at the bottom of bags when stored at $30^{\circ} \mathrm{C}$ for 45 days. Therefore, it is expected that lowering moisture contents through addition of high DM materials such as wheat bran and dried beet pulp might be more effective for preservation.

The $\mathrm{NH}_{3}-\mathrm{N}$ content was largely unchanged during 

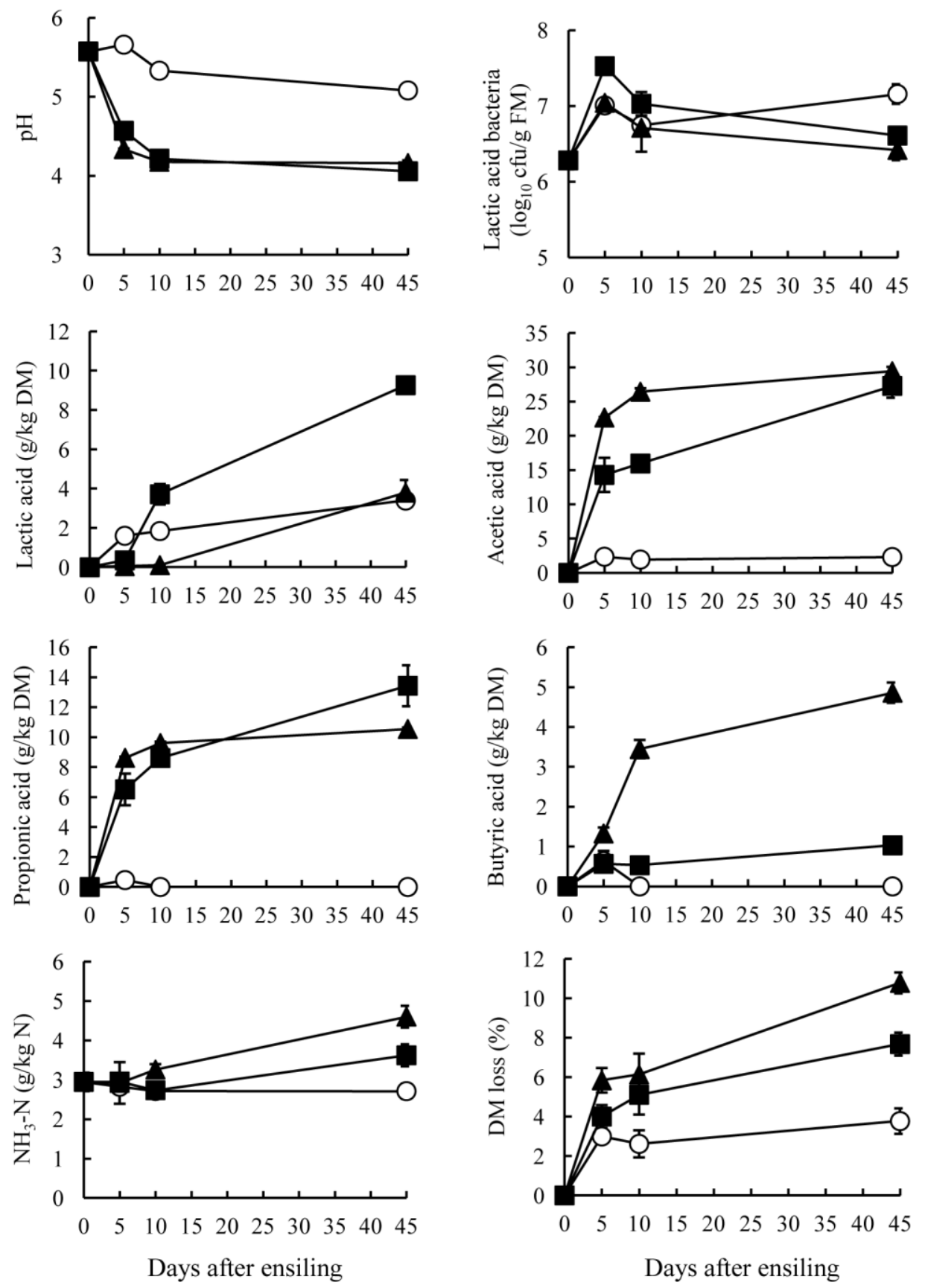

Figure 1. Changes in $\mathrm{pH}$, numbers of lactic acid bacteria, fermented products, and DM loss of green tea by-product silage ensiled at $10^{\circ} \mathrm{C}(\mathrm{\circ}), 20^{\circ} \mathrm{C}(\boldsymbol{\square})$ and $30^{\circ} \mathrm{C}(\boldsymbol{\Delta})$. Data were collected on $0,5,10$, and 45 days after ensiling. Points indicate mean values of triplicates silos with standard errors represented by vertical bars.

ensiling and was low $(<5 \mathrm{~g} / \mathrm{kg} \mathrm{N})$ indicating that proteolysis in tea by-product occurred only slightly during ensiling. In general, low $\mathrm{pH}$ suppresses the growth of proteolytic bacteria, such as clostridia, thereby engendering low $\mathrm{NH}_{3}-\mathrm{N}$ contents. In tea by-product silage, it was also presumed that phenolic compounds in tea by-products suppressed clostridial fermentation, which is supported by Ishihara et al. (2001) who reported that tea polyphenols numerically decreased clostridia in bovine intestines. Low $\mathrm{NH}_{3}-\mathrm{N}$ contents in GTS and BTS might also be attributable to heatdamaged protein when processing tea leaves after harvesting (Graham, 1992). Another mechanism of the low proteolysis might be occurred by the presence of tanninprotein complexes in GTS and BTS. It had been reported that tannins are interacted with plant leaf protein and make insoluble complexes under pH 3.5 to 5.5 (Perez-Maldonado et al., 1995). The $\mathrm{pH}$ of GTS and BTS on 45 days after ensiling ranged from 4.1 to 5.3 in the present study that 

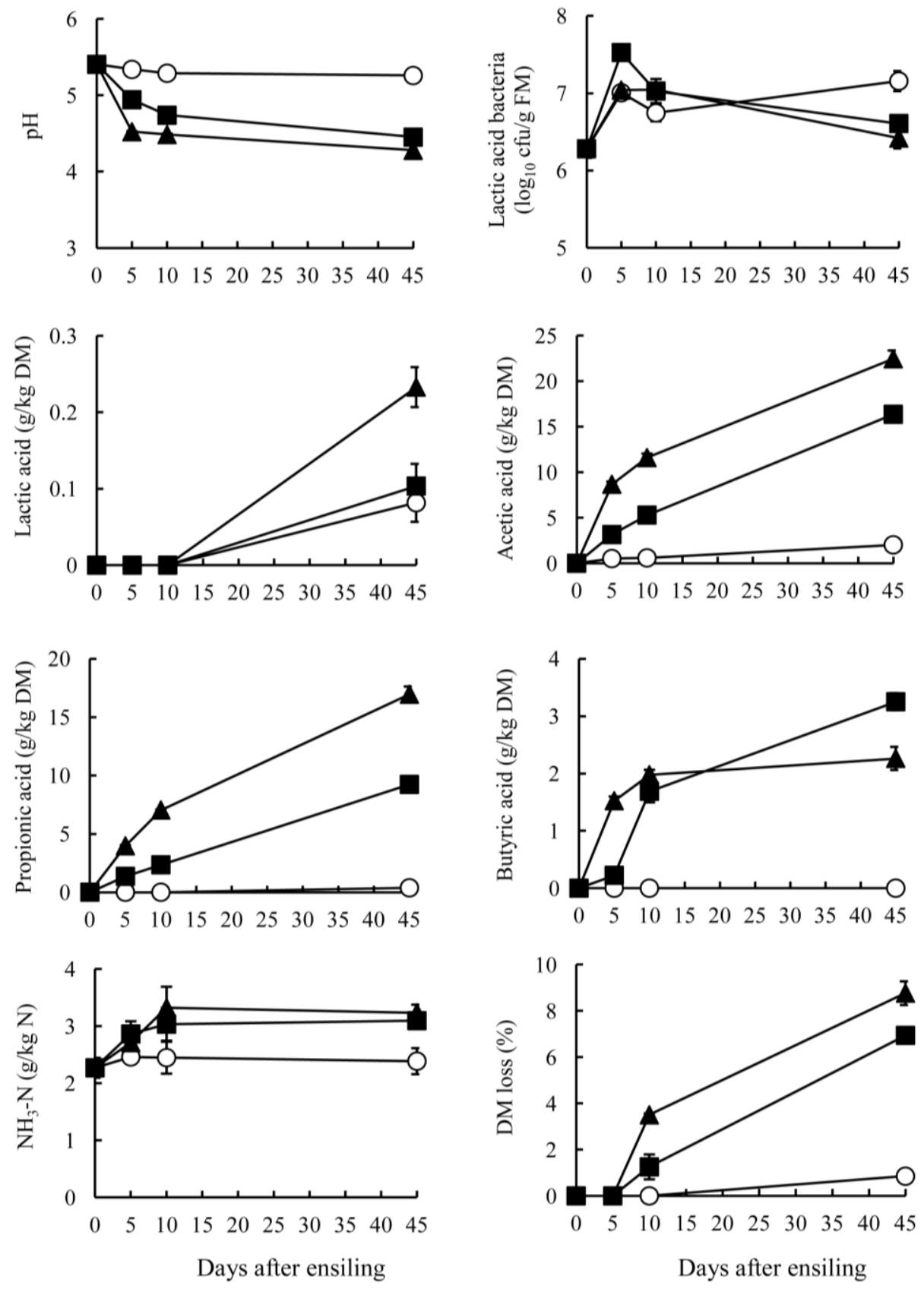

Figure 2. Changes in $\mathrm{pH}$, numbers of lactic acid bacteria, fermented products, and DM loss of black tea by-product silage ensiled at $10^{\circ} \mathrm{C}(\circ), 20^{\circ} \mathrm{C}(\boldsymbol{\bullet})$ and $30^{\circ} \mathrm{C}(\boldsymbol{\Delta})$. Data were collected on $0,5,10$, and 45 days after ensiling. Points indicate mean values of triplicates silos with standard errors represented by vertical bars.

indicated some parts of proteins in GTS and BTS made complexes with tannins. It can also be estimated that these complexes cannot be degraded during ensiling since Albrecht and Muck (1991) reported that a negative correlation between tannin contents and non-protein $\mathrm{N}$ concentrations in legume silage. Salawu et al. (1999) also demonstrated that the contents of soluble proteins in grass silage decreased through addition of tannin powder. According to these reports, GTS and BTS could be expected to have several factors including tannins and form of proteins that prevent from proteolysis during ensiling. The DM loss of GTS stored at $30^{\circ} \mathrm{C}$ was highest, followed by $20^{\circ} \mathrm{C}$ and $10^{\circ} \mathrm{C}(\mathrm{p}<0.05)$. The loss of GTS occurred mainly during 5 days after ensiling; after 10 days, a greater DM loss was apparent at $20^{\circ} \mathrm{C}$ and $30^{\circ} \mathrm{C}$, but stable at $10^{\circ} \mathrm{C}$. On the other hand, the DM loss of BTS occurred mainly 10 days after ensiling. These results also supported the difference of fermentation status between GTS and BTS, as discussed above. 
Chemical composition of tea by-products ensiled at different temperatures

Proteins, fibers and phenolic compounds of GTS and BTS are presented in Table 2 and Figure 3. Protein fractions and fiber content were significantly affected by ensiling temperature $(p<0.05)$. Ensiling temperatures did not affect TEPH and TET contents on day 45 in either GTS or BTS, but temperature did affect the CT contents. In GTS, CT content at $20^{\circ} \mathrm{C}$ and $30^{\circ} \mathrm{C}$ was significantly lower than at $10^{\circ} \mathrm{C}(\mathrm{p}<0.05)$. The $\mathrm{CT}$ contents in GTS stored at $20^{\circ} \mathrm{C}$ and $30^{\circ} \mathrm{C}$ decreased at early stages of ensiling, but increased at $10^{\circ} \mathrm{C}$ (Figure 3). Our previous reports also showed that CT contents in mixed silage including green tea by-product stored at $30^{\circ} \mathrm{C}$ was lower than at $15^{\circ} \mathrm{C}$ (Kondo et al., 2006). These results demonstrate that $\mathrm{CT}$ in green tea by-product might be degraded in higher temperatures. Although statistical differences were apparent for CT contents in BTS, the contents were not changed greatly by ensiling temperature. Ott et al. (2005) reported that TEPH, TET, and CT in tannin-containing sorghum grain decreased during ensiling. Osawa et al. (2000) identified lactobacilli producing tannin-degrading enzyme from fermented foods. Therefore, it would be possible to cleave the molecular bond in phenolics during ensiling. On the other hand, some reports have shown the increase of TEPH content during fermentation process, as shown in pearl millet and oat (Khetarpaul and Chauhan, 1991; Kondo et al., 2004b). Nishino et al. (2007) reported that the changes of major polyphneol molecules in green tea leaf during ensiling and showed that TEPH content slightly increased, while the content of (-)-epicatechin gallate (ECG) and (-)-
Table 2. Chemical composition of green and black tea by-product silage on 45 days after ensiling at different temperatures

\begin{tabular}{lcccc}
\hline Attributes & $10^{\circ} \mathrm{C}$ & $20^{\circ} \mathrm{C}$ & $30^{\circ} \mathrm{C}$ & SEM \\
\hline Green tea by-product silage & & & & \\
CP $(\mathrm{g} / \mathrm{kg} \mathrm{DM})$ & 307 & 316 & 292 & 5.6 \\
NDICP $(\mathrm{g} / \mathrm{kg} \mathrm{CP})$ & $121^{\mathrm{b}}$ & $115^{\mathrm{b}}$ & $135^{\mathrm{a}}$ & 2.8 \\
ADICP $(\mathrm{g} / \mathrm{kg} \mathrm{CP})$ & $57^{\mathrm{b}}$ & $66^{\mathrm{a}}$ & $68^{\mathrm{a}}$ & 1.8 \\
NDF $(\mathrm{g} / \mathrm{kg} \mathrm{DM})$ & 358 & 351 & 368 & 6.7 \\
ADF $(\mathrm{g} / \mathrm{kg} \mathrm{DM})$ & 277 & 296 & 303 & 6.9 \\
ADL $(\mathrm{g} / \mathrm{kg} \mathrm{DM})$ & $91^{\mathrm{b}}$ & $101^{\mathrm{a}}$ & $104^{\mathrm{a}}$ & 1.8 \\
Hemicellulose $(\mathrm{g} / \mathrm{kg} \mathrm{DM})$ & $81^{\mathrm{a}}$ & $55^{\mathrm{c}}$ & $65^{\mathrm{b}}$ & 2.2 \\
Cellulose $(\mathrm{g} / \mathrm{kg} \mathrm{DM})$ & 187 & 196 & 198 & 5.1 \\
TEPH $(\mathrm{g} / \mathrm{kg} \mathrm{DM})$ & 87 & 98 & 92 & 4.3 \\
TET $(\mathrm{g} / \mathrm{kg} \mathrm{DM})$ & 71 & 77 & 73 & 4.0 \\
CT $(\mathrm{g} / \mathrm{kg} \mathrm{DM})$ & $35^{\mathrm{a}}$ & $9^{\mathrm{b}}$ & $11^{\mathrm{b}}$ & 1.3 \\
Black tea by-product silage & & & & \\
CP $(\mathrm{g} / \mathrm{kg} \mathrm{DM})$ & $287^{\mathrm{c}}$ & $306^{\mathrm{b}}$ & $313^{\mathrm{a}}$ & 1.3 \\
NDICP $(\mathrm{g} / \mathrm{kg} \mathrm{CP})$ & 539 & 529 & 554 & 6.7 \\
ADICP $(\mathrm{g} / \mathrm{kg} \mathrm{CP})$ & $102^{\mathrm{a}}$ & $87^{\mathrm{b}}$ & $78^{\mathrm{c}}$ & 2.0 \\
NDF $(\mathrm{g} / \mathrm{kg} \mathrm{DM})$ & $479^{\mathrm{b}}$ & $493^{\mathrm{b}}$ & $520^{\mathrm{a}}$ & 7.3 \\
ADF $(\mathrm{g} / \mathrm{kg} \mathrm{DM})$ & 246 & 250 & 255 & 4.9 \\
ADL $(\mathrm{g} / \mathrm{kg} \mathrm{DM})$ & 83 & 86 & 84 & 5.0 \\
Hemicellulose $(\mathrm{g} / \mathrm{kg} \mathrm{DM})$ & 234 & 243 & 265 & 8.2 \\
Cellulose $(\mathrm{g} / \mathrm{kg} \mathrm{DM})$ & 163 & 163 & 171 & 3.8 \\
TEPH $(\mathrm{g} / \mathrm{kg} \mathrm{DM})$ & 95 & 94 & 91 & 2.2 \\
TET $(\mathrm{g} / \mathrm{kg} \mathrm{DM})$ & 69 & 70 & 64 & 2.2 \\
CT $(\mathrm{g} / \mathrm{kg} \mathrm{DM})$ & $12^{\mathrm{a}}$ & $10^{\mathrm{b}}$ & $12^{\mathrm{a}}$ & 0.4 \\
\hline
\end{tabular}

SEM, standard error of the mean; CP, crude protein; NDICP, neutral detergent insoluble CP; ADICP, acid detergent insoluble CP; NDF, neutral detergent fiber; ADF, acid detergent fiber; ADL, acid detergent lignin; TEPH, total extractable phenolics; TET, total extractable tannins; CT, condensed tannins.

Means with the different letter (a-c) in a row are significantly different $(\mathrm{p}<0.05)$.
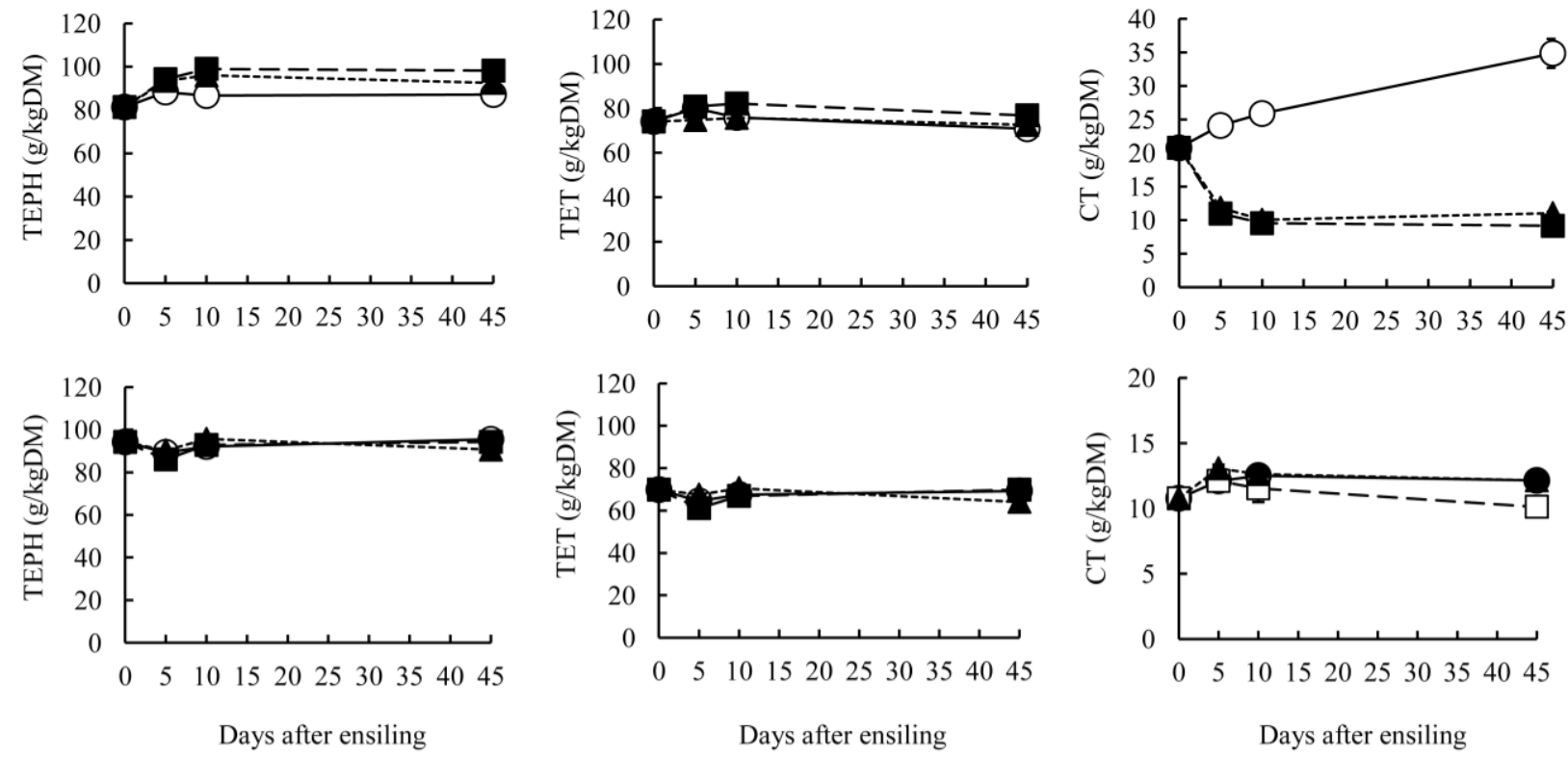

Figure 3. Changes in total extractable phenolics (TEPH), total extractable tannins (TET) and condensed tannins (CT) of green (above) and black (below) tea by-product silage stored at $10^{\circ} \mathrm{C}(\circ), 20^{\circ} \mathrm{C}(\boldsymbol{\bullet})$ and $30^{\circ} \mathrm{C}(\boldsymbol{\Delta})$. Data were collected on $0,5,10$, and 45 days after ensiling. Points indicate mean values of triplicates silos with standard errors represented by vertical bars. 
epigallocatechin gallate (EGCG) decreased, but that of (-)epigallocatechin did not change. Their report implied that gallic acid of B-ring in ECG and EGCG can be liberated. The Folin-Ciocalteu methods to determine TEPH and TET contents are based on the reducing power of hydroxyl function of phenolics to molybdic acid. Therefore, the reaction to Folin solutions would not correspond directly to the amounts of phenolic compounds. It is possible that the reducing power was increased by cleavage of small amount of high molecular phenolic compounds to large amounts of low molecular phenolics. These differences among the studies of tannin contents during ensiling are attributable to various structures of phenolic compounds in plants.

\section{In vitro ruminal fermentation}

Both gas production and ruminal $\mathrm{NH}_{3}-\mathrm{N}$ concentration were higher in GTS than those in BTS, indicating the higher nutritive potential of GTS as compared to BTS. Higher ensiling temperatures showed significantly lower gas production $(\mathrm{p}<0.05$, Table 3$)$, which would result from the fact that the loss of fermentable carbohydrates during ensiling was higher at $20^{\circ} \mathrm{C}$ and $30^{\circ} \mathrm{C}$ than at $10^{\circ} \mathrm{C}$. In vitro gas production test with PEG on tannin-rich forage has been a valuable tool to assess effects of tannin on feed degradation in the rumen (Makkar et al., 1995; Getachew et al., 2000). Many researches showed that PEG addition increased in vitro gas production from most of tannin rich feeds (Getachew et al., 2000; Rubanza et al., 2003; Osuga et al., 2007). In the present study, despite the presence of tannins in GTS, gas production was not altered by PEG addition, accorded with some browse reported in Singh et al. (2005) and Osuga et al. (2007). Although it can be expected to have an increase in substrate degradability if tannins activity is reduced by PEG addition, a simultaneous large increase in gas production could simply a result in lower partitioning of nutrients to microbial protein synthesis (Singh et al., 2005). Gas production is a result of feed fermentation in rumen. Proportion of fermentation products depends on feed, especially $\mathrm{CP}$ and carbohydrates. But most of $\mathrm{CP}$ is degraded to amino acids and $\mathrm{NH}_{3}$, and give less gas. GTS could contain more degradable protein than BTS as expected from lower NDICP content in GTS. Small response of gas production to PEG addition from GTS implies that higher partitioning of fermentable nutrients in GTS to microbial protein synthesis. It can be also inferred that less contribution to gas production from fermentable carbohydrate in GTS due to supplemental tannin binding agents. On the contrary, the amount of gas produced from BTS was increased by PEG addition. The ratio of increase in BTS was unaffected by the ensiling temperature, which means that the ensiling temperature did not influence the extent of suppressive effect of BTS tannin on the ruminal gas production. The $\mathrm{NH}_{3}-\mathrm{N}$ concentration was increased by PEG addition from both GTS and BTS. These results were similar to those reported using tannin-containing tropical browse (Getachew et al., 2000). Tannins depress ruminal

Table 3. Effect of polyethylene glycol (PEG) treatment on in vitro gas production and ammonia nitrogen $\left(\mathrm{NH}_{3}-\mathrm{N}\right)$ from green and black tea by-product silage at $24 \mathrm{~h}$ after incubation

\begin{tabular}{|c|c|c|c|c|c|}
\hline \multirow{2}{*}{ Attributes } & \multirow{2}{*}{ Day 0} & \multicolumn{3}{|c|}{ Day 45} & \multirow{2}{*}{ SEM } \\
\hline & & $10^{\circ} \mathrm{C}$ & $20^{\circ} \mathrm{C}$ & $30^{\circ} \mathrm{C}$ & \\
\hline \multicolumn{6}{|c|}{ Gas production (mL/500 mg DM) } \\
\hline \multicolumn{6}{|c|}{ Green tea by-product silage } \\
\hline No PEG & 83.9 & $76.4^{\mathrm{a}}$ & $68.2^{\mathrm{b}}$ & $63.8^{\mathrm{b}}$ & 1.9 \\
\hline With PEG & 85.3 & $77.3^{\mathrm{a}}$ & $69.7^{\mathrm{b}}$ & $64.0^{\mathrm{c}}$ & 1.2 \\
\hline Increase $(\%)$ & 1.7 & 1.1 & 2.2 & 0.4 & 1.8 \\
\hline \multicolumn{6}{|c|}{ Black tea by-product silage } \\
\hline No PEG & 58.4 & $54.8^{\mathrm{a}}$ & $47.7^{\mathrm{b}}$ & $43.9^{c}$ & 0.6 \\
\hline With PEG & 65.2 & $61.2^{\mathrm{a}, *}$ & $52.8^{\mathrm{b}, *}$ & $48.5^{\mathrm{c}, *}$ & 0.3 \\
\hline Increase $(\%)$ & 11.7 & 11.6 & 10.7 & 10.6 & 1.9 \\
\hline \multicolumn{6}{|c|}{$\mathrm{NH}_{3}-\mathrm{N}(\mathrm{mg} / 40 \mathrm{~mL} / 500 \mathrm{mg} \mathrm{DM})$} \\
\hline \multicolumn{6}{|c|}{ Green tea by-product silage } \\
\hline No PEG & 6.3 & $7.0^{\mathrm{b}}$ & $8.2^{\mathrm{a}}$ & $8.1^{\mathrm{a}}$ & 0.4 \\
\hline With PEG & 9.0 & $10.0^{\mathrm{b}, *}$ & $11.7^{\mathrm{a}, *}$ & $11.1^{\mathrm{ab}, *}$ & 0.9 \\
\hline Increase $(\%)$ & 43.3 & 42.2 & 43.6 & 38.0 & 3.5 \\
\hline \multicolumn{6}{|c|}{ Black tea by-product silage } \\
\hline No PEG & 5.3 & $4.6^{\mathrm{b}}$ & $5.5^{\mathrm{a}}$ & $5.7^{\mathrm{a}}$ & 0.4 \\
\hline With PEG & 8.3 & $8.3^{\mathrm{b}, *}$ & $9.2^{\mathrm{a}, *}$ & $8.6^{\mathrm{ab}, *}$ & 0.2 \\
\hline Increase $(\%)$ & 56.7 & $82.2^{\mathrm{a}}$ & $65.8^{\mathrm{b}}$ & $51.8^{\mathrm{c}}$ & 3.4 \\
\hline
\end{tabular}

SEM, standard error of the mean; DM, dry matter.

Means with the different letter $(a-c)$ in a row are significantly different $(p<0.05)$. * Significantly different between No PEG ( $<<0.05)$. 
degradation of proteins due to strongly binding with proteins in feed and/or microbial enzymes in rumen (Makkar et al., 1995). Among the tannin-protein complex, several interaction types such as hydrogen bonding, hydrophobic bonding can take place in principle (Oh et al., 1980). The PEG contains more effective cites (oxygen of ether linkage) which bind with hydroxyl group of tannins (Jones, 1965). The PEG as a tannin-binding agent has a high affinity to tannins and deactivate tannin's binding activity to proteins, and can be expected that PEG makes tannin-bound protein available to microbial degradation (Makkar et al., 1995). The response of improved $\mathrm{NH}_{3}-\mathrm{N}$ concentration resulting from PEG treatment mainly reflects deactivation of tannin. In the present study, despite similarity in the amounts of tannins in GTS and BTS, relatively lower increase ratio in $\mathrm{NH}_{3}-\mathrm{N}$ by PEG existed in GTS (38\% to $44 \%$ ) than in BTS (52\% to $82 \%$ ). This indicated that tannins in GTS had a lower anti-nutritional activity than that in BTS when ensiled any temperature, and protein in GTS was relatively degradable than that in BTS.

\section{CONCLUSION}

Ensiling did not affect TEPH and TET contents in either GTS or BTS. The CT contents in GTS could be partly lowered during ensiling at high temperature, but the storage temperature did not affect the suppressive activity of tannins in tea by-products based on in vitro ruminal fermentation test. Lower responses to PEG on gas production and $\mathrm{NH}_{3}-\mathrm{N}$ concentration from GTS than BTS at any ensiled temperature indicated that tannins in GTS could suppress rumen fermentation more weakly than that in BTS. Further studies are recommended for assessment of the nutritional value of GTS and BTS as protein supplements, compared with commercial protein-rich feedstuffs by in vitro and in vivo digestibility trials.

\section{ACKNOWLEDGMENTS}

The authors are grateful to POKKA Corporation (Aichi, Japan) for providing the tea by-products. We wish to thank the members of the Laboratory of Animal Production Sciences in Nagoya University for making GTS and BTS. M. Kondo is indebted to Mrs K. Goto for her helping with chemical analyses.

\section{REFERENCES}

Albrecht, K. A. and R. E. Muck. 1991. Proteolysis in ensiled forage legumes that vary in tannin concentration. Crop. Sci. 31:464-469.

Barnett, A. J. G. 1951. The colorimetric determination of lactic acid in silage. Biochem. J. 49:527-529.
Bhatta, R., M. Saravanan, B, Luna, and K. T. Sampath. 2012. Phenolic composition, fermentation profile, protozoa population and methane production from sheanut (Butryospermum Parkii) byproducts in vitro. Asian Australas. J. Anim. Sci. 25:1389-1394.

Getachew, G., H. P. S. Makkar, and K. Becker. 2000. Effect of polyethylene glycol on in vitro degradability of nitrogen and microbial protein synthesis from tannin-rich browse and herbaceous legumes. Br. J. Nutr. 84:73-83.

Graham, H. N. 1992. Green tea composition, consumption, and polyphenol chemistry. Prev. Med. 21:334-350.

Hymes-Fecht, U. C., G. A. Broderick, R. E. Muck, and J. H. Grabber. 2013. Replacing alfalfa or red clover silage with birdsfoot trefoil silage in total mixed rations increases production of lactating dairy cows. J. Dairy Sci. 96:460-469.

Ishihara, N., D. C. Chu, S. Akashi, and L. R. Juneja. 2001. Improvement of intestinal microflora balance and prevention of digestive and respiratory organ diseases in calves by green tea extracts. Livest. Prod. Sci. 68:217-229.

Jones, D. E. 1965. Banana tannin and its reaction with polyethylene glycols. Nature 206:299-300.

Khetarpaul, N. and B. M. Chauhan. 1991. Effect of natural fermentaion on phytate and polyphenol content and in vitro digestibility of starch and protein of pearl millet (Pennisetum typhoideum). J. Sci. Food Agric. 55:189-195.

Koehler, L. H. 1952. Differentiation of carbohydrates by anthrone reaction rate and color intensity. Anal. Chem. 24:1576-1579.

Kondo, M., K. Kita, and H. Yokota. 2004a. Effects of tea leaf waste of green tea, oolong tea, and black tea addition on sudangrass silage quality and in vitro gas production. J. Sci. Food Agric. 84:721-727.

Kondo, M., K. Kita, and H. Yokota. 2004b. Feeding value to goats of whole-crop oat ensiled with green tea waste. Anim. Feed Sci. Technol. 113:71-81.

Kondo, M., K. Kita, and H. Yokota. 2006. Evaluation of fermentation characteristics and nutritive value of green tea waste ensiled with byproducts mixture for ruminants. Asian Australas. J. Anim. Sci. 19:533-540.

Kozloski, G. V., C. J. Harter, F. Hentz, S. C. de Avilar, T. Orlandi, and C. M. Stefanello. 2012. Intake, digestibility and nutrients supply to wethers fed ryegrass and intraruminally infused with levels of Acacia mearnsii tannin extract. Small Rumin. Res. 106:125-130

Licitra, G., T. M. Hernandez, and P. J. Van Soest. 1996. Standarization of procedures for nitrogen fractionation of ruminant feed. Anim. Feed Sci. Technol. 57:347-358.

Makkar, H. P. S., M. Blummel, and K. Becker. 1995. Formation of complexes between polyvinyl pyrrolidones or polyethylene glycols and tannins, and their implication in gas production and true digestibility in in vitro techniques. Br. J. Nutr. 73:897913.

Makkar, H. P. S. and A. V. Goodchild. 1996. Quantification of Tannins: A Laboratory Manual. ICARDA, Aleppo, Syria.

McDonald, P., A. R. Henderson, and S. J. Heron. 1991. The Biochemistry of Silage, 2nd Edn. Chalcombe Publications, Aberystwyth, UK. pp. 31-32.

Menke, K. H. and H. Stengass. 1988. Estimation of the energetic feed value obtained from chemical analysis and in vitro gas production using rumen fluid. Anim. Res. Develop. 28:7-55. 
Mokhtarpour, A., A. Naserian, A. M. Tahmasbi, and R. Valizadeh. 2012. Effect of feeding pistachio by-products silage supplemented with polyethylene glycol and urea on Holstein dairy cows performance in early lactation. Livest. Sci. 148: 208-213.

Nishino, N., H. Harada, and E. Sakaguchi. 2003. Evaluation of fermentation and aerobic stability of wet brewers's grains ensiled alone or in combination with various feeds as a total mixed ration. J. Sci. Food Agric. 83:557-563.

Nishino, N., T. Kawai, and M. Kondo. 2007. Changes during ensilage in fermentation products, tea catechins, antioxidative activity and in vitro gas production of green tea waste stored with or without dried beet pulp. J. Sci. Food Agric. 87:16391644.

Oh, H., I., J. E. Hoff, G. S. Armstrong, and L. A. Haff. 1980. Hydrophobic interaction in tannin-protein complexes. J. Agric. Food Chem. 28:394-398.

Osawa, R., K. Kuroiso, S. Goto, and A. Shimizu. 2000. Isolation of tannin-degrading lactobacilli from humans and fermented foods. Appl. Environ. Microbiol. 66:3093-3097.

Osuga, I. M., S. A. Abdulrazak1, T. Ichinohe, and T. Fujihara. 2005. Chemical composition, degradation characteristics and effect of tannin on digestibility of some browse species from Kenya harvested during the wet season. Asian Australas. J. Anim. Sci. 18:54-60.

Osuga, I. M., C. N. Maindi, S. A. Abdulrazak, N. Nishino, T. Ichinohe, and T. Fujihara. 2007. Potential nutritive value and tannin bioassay of selected Acacia species from Kenya. J. Sci. Food. Agric. 87:1533-1538.

Ott, E. M., M. Aragon, and M. Gabel. 2005. Ensiling of tannincontaining sorghum grain. Silage production and utilisation. Prceedings of the XIVth International Silage Conference. pp. 178.

Pathak, A. K., N. Dutta, P. S. Banerjee, A. K. Patthanaik, and K. Sharma. 2013. Influence of dietary supplementation of condensed tannins through leaf meal mixture on intake, nutrient utilization and performance of Haemonchus contortus infected sheep. Asian Australas. J. Anim. Sci. 26:1446-1458.

Playne, M. J. and P. McDonald. 1966. The buffering constituents of herbage and of silage. J. Sci. Food Agric. 17:264-268.
Perez-Maldonado, R. A., B. W. Norton, and G. L. Kerven. 1995. Factors affecting in vitro formation of tannin-protein complexes. J. Sci. Food Agric. 69:291-298.

Ramdani, D., A. S. Chaudhry, and C. J. Seal. 2013. Chemical composition, plant secondary metabolites, and minerals of green and black teas and the effect of different tea-to-water ratios during their extraction on the composition of their spent leaves as potential additives for ruminants. J. Agric. Food Chem. 61:4961-4967.

Rubanza, C. D. K., M. N. Shem, R. Otsyina, N. Nishino, T. Ichinohe, and T. Fujihara. 2003. Content of phenolics and tannins in leaves and pods of some Acacia and Dichrostachys species and effects on in vitro digestibility. J. Anim. Feed Sci. 12:645-663.

Salawu, M. B., T. Acamovic, C. S. Stewart, T. Hvelplund, and M. R. Weisbjerg. 1999. The use of tannins as silage additives: Effects on silage composition and mobile bag disappearance of dry matter and protein. Anim. Feed Sci. Technol. 82:243-259.

Singh, B., A. Sahoo, R. Sharma, and T. K. Bhat. 2005. Effect of polethylene glycol on gas production parameters and nitrogen disappearance of some tree forages. Anim. Feed Sci. Technol. 123-124: 351-364.

Tan, H. Y., C. C. Sieo, N. Abdullah, J. B. Liang, X. D. Huang, and Y. W. Ho. 2011. Effects of condensed tannins from Leucaena on methane production, rumen fermentation and populations of methanogens and protozoa in vitro. Anim. Feed Sci. Technol. 169:185-193

Van Soest, P. J., J. D. Robertson, and B. A. Lewis. 1991. Methods for dietary fiber, neutral detergent fiber, and nonstarch polysaccharides in relation to animal nutrition. J. Dairy Sci. 74:3583-3597.

Waghorn, G. C. 2008. Beneficial and detrimental effects of dietary condensed tannins for sustainable sheep and goat productionProgress and challenges. Anim. Feed Sci. Technol. 147:116139 .

Wang, R. R., H. L. Wang, X. Liu, and C. C. Xu. 2011. Effects of different additives on fermentation characteristics and protein degradation of green tea grounds silage. Asian Australas. J. Anim. Sci. 24:616-622.

Weatherburn, M. W. 1967. Phenol-hypochlorite reaction for determination of ammonia. Anal. Chem. 39:971-974. 